\title{
RANCANG BANGUN SISTEM GERAK PANEL SURYA BERBASIS ARDUINO UNO
}

\section{Titien Kumala Sari ${ }^{(1)}$, Toibah Umi Kalsum(2),}

\author{
${ }^{1)}$ Study Program Of Computer Systems Engineering Faculty Of Computer \\ Universitas Dehasen Bengkulu \\ 2)Departemen of Computer Systems Engineering Faculty Of Computer, \\ universitas Dehasen Bengkulu \\ Email: ${ }^{1)}$ TitienKumala Sari@gmail.com) $;{ }^{2)}$ Cicik.umie@gmail.com
}

\begin{abstract}
How to Cite :
Titien Kumala Sari, Toibah Umi Kalsum. 2020. RANCANG BANGUN SISTEM GERAK PANEL SURYA BERBASIS ARDUINO UNO.

DOI:https://doi.org/10.37638/gatotkaca.1.1.14-28
\end{abstract}

\section{ARTICLE HISTORY \\ Received [12Januari 2020] \\ Revised [16 Februari 2020] \\ Accepted [20 Maret 2020]}

\section{KEYWORDS}

SolarPanel,MotorDriver,

RTC, Arduino UNO

Information :

1: Student

2: Supervisors

This is an open access article under the $\underline{C C-B Y-S A}$ license

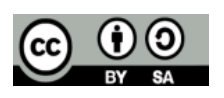

\section{ABSTRAK}

Ringkasan,- Panel Surya (Panel Photovoltaik) adalah suatu panel yang terdiri dari kumpulan sel surya berfungsi merubah energi cahaya menjadi energi listrik dengan memanfaatkan efek photovoltaik. Photovoltaik dapat diartikan sebagai "cahaya-listrik". Sel surya atau sel PV bergantung pada efek photovoltaik untuk menyerap energi matahari dan menyebabkan arus mengalir antara dua lapisan bermuatan yang berlawanan. Pada umumnya modul photovoltaik dipasarkan dengan kapasitas 50 Watt-peak (Wp) dan kelipatannya. Unit satuan Watt-peak adalah satuan daya (Watt) yang dapat dibangkitkan oleh modul photovoltaik dalam keadaan standar uji (Standard Test Condition - STC). Penggunaan arduino uno pada panel surya ini tujuannya agar pengaturan arah panel surya selalu tegak lurus dengan arah cahaya matahari. Dengan demikian dibuat sebuah sistem kontrol yang dapat mengatur arah panel surya secara otomatis melalui pengerak driver motor.

Hasil analisa sistem gerak panel surya berbasis Arduino Uno, pada Panel Surya ini menggunakan Arduino Uno sebagai sistem gerak untuk mengikuti arah matahari, RTC digunakan sebagai penerimaan perintah yang dikirim melalui panel surya agar dapa membaca kisaran sudut, stepper difungsikan sebagai penggerak panel surya yang dikendalikan menggunakan Arduino UNO menggunakan aplikasi. Hasil yang optimal terdapat pada jam 11.00 - 12.00 wib karena cahaya matahari lebih terik dari waktu pagi dan sore. Hasil arus dan tegangan sesuai yang didapatkan karena pengoptimal arus dan tegangan pada panel surya bergerak lebih efisien. 


\section{ABSTRACT}

The Solar Panel (Photovoltaic Panel) is a panel consisting of a collection of solar cells that functions to convert light energy into electrical energy by utilizing photovoltaic effects. Photovoltaics can be interpreted as "light-electricity". Solar cells or PV cells depend on photovoltaic effects to absorb solar energy and cause current to flow between two opposite charged layers. In general, photovoltaic modules are marketed with a capacity of 50 Watt-peak (Wp) and multiples thereof. Watt-peak units are units of power (Watts) that can be generated by photovoltaic modules in standard test conditions (STC). The use of Arduino Uno on solar panels is intended to regulate the direction of the solar panel always perpendicular to the direction of sunlight. Thus, a control system is created that can automatically adjust the direction of the solar panel through the driver of the motor. The results of the analysis of the motion of solar panels based on Arduino Uno, in this Solar Panel using Arduino Uno as a motion system to follow the direction of the sun, RTC is used as receiving commands sent through solar panels so that they can read the angle range, stepper functioned as a solar panel driven Arduino UNO uses the application. Optimal results are available at $11.00-12.00$ WIB because the sun's rays are hotter than morning and evening. The current and voltage results are as obtained because the current and voltage optimizers in solar panels move more efficiently.

\section{PENDAHULUAN}

Listrik merupakan salah satu kebutuhan yang penting, energy tersebut juga bisa bersumber dari energi matahari yang dikonversikan menjadi energi listrik dengan memanfaatkan panelsurya. Penggunaan panel surya di indonesia sangat cocok karena indonesia merupakan negara tropis sehingga mendapatkan pancaran sinar matahari yang bagus, akan tetapi energi ini kurang dimanfaatkan secara optimal. Panel surya yang terpasang selama ini masih bersifat statis (tidak mengikuti pergerakan matahari), maka panelsurya tidak dapa tmenangkap cahaya secara maksimal pancaran sinar matahari sepanjang siang hari.

Pemanfaatanenergi matahari atau energi alternatif yang terbarukan sebagai pembangkit listrik mempunyai peran yang sangat penting dalam memenuhi kebutuhan energi. Hal ini disebabkan penggunaan daya listrik masih banyak menggunakan bahan bakar seperti bahan bakar utama batubara.

Dalam penelitian ini dirancang suatu sistem panel surya berbasis Arduino sebagai penyuplai utama energy listrik. Sistem ini bekerja untuk saling mengsupport agar mendapatkan energy matahari secara maksimal dan panel surya bisa bergerak mengikuti cahaya matahari.

Berdasarkan uraian latar belakang diatas, penulis tertarik untuk mengangkat judul penelitian "Rancang Bangun Sistem Gerak Panel Surya Berbasis Arduino Uno". 


\section{LANDASAN TEORI}

\section{Untuk Kerja}

Menurut Hamzah B Uno(2012:19),Unjuk kerja merupakan penilaian yang dilakukan den gan mengamati kegiatan dalam melakukan sesuatu.Unjuk kerja yang diamati seperti $\mathrm{m}$ enggunakan peralatan laboratorium,dan mengoperasikan suatu alat.Menurut Bambang Subali (2010:16)Unjuk kerja adalah penilaian yang memfokuskan aspek keterampilan y ang berkait dengan karya yang dapat didemonstrasikan.Dilihat dari kinerja atau kemam puan yang didemonstrasikan.

\section{Sistem Gerak}

Pengertian Sistem Menurut Jogianto (2005 : 2) mengemukakan bahwa system adalah kumpulan dari elemen elemen yang berinteraksi untuk mencapai suatu tujuan tertentu.s istem ini menggambarkan suatu kejadian kejadian dan kesatuan yang nyata adalah sua tu objek nyata,seperti tempat, benda,dan orang orang yang betul betul ada dan terjadi.

\section{Pengertian Sistem Secara Umum}

Sistem berasal dari bahasa Latin (systēma) dan bahasa Yunani (sustēma) adalah suatu kesatuan yang terdiri komponen atau elemen yang dihubungkan bersama untuk memudahkan aliran informasi, materi atau energi untuk mencapai suatu tujuan. Istilah ini sering dipergunakan untuk menggambarkan suatu setentitas yang berinteraksi, di mana suatu model matematika seringkali bisa dibuat.

\section{Panel Surya}

Menurut Jurnal (Jom FTEKNIK Volume 4 No. 2 Oktober 2017), Panel Surya (Panel Photovoltaik) adalah suatu panel yang terdiri dari kumpulan sel surya berfungsi merubah energi cahaya menjadi energi listrik dengan memanfaatkan efek photovoltaik. Photovoltaik dapat diartikan sebagai "cahaya-listrik". Sel surya atau sel PV bergantung pada efek photovoltaik untuk menyerap energi matahari dan menyebabkan arus mengalir antara dua lapisan bermuatan yang berlawanan. Pada umumnya modul photovoltaik dipasarkan dengan kapasitas 50 Watt-peak (Wp) dan kelipatannya. Unit satuan Watt-peak adalah satuan daya (Watt) yang dapat dibangkitkan oleh modul photovoltaik dalam keadaan standar uji (Standard Test Condition - STC).

\section{Arduino Uno}

Menurut (FeriDjuandi, 2011) Arduinoadalahmerupakansebuah board minimum system mikrokontroler yang bersifatopen source.Didalamrangkaianboard arduinoterdapatmikrokontroler AVR seriATMega 328 yang merupakanprodukdari Atmel.

Arduino adalah pengendali mikro single-board yang bersifat open source, diturunkan dari wiring platform, dirancang untuk memudahkan untuk penggunaan elektronik dalam berbagai bidang. Softwarenya memiliki bahasa program sendiri.

\section{METODE PENELITIAN}

\section{Metode Pengumpulan Data}

Menurut Azwar (2007: 110), Metode penelitian yang digunakan adalah metode eksprimen. Pada penelitian yang dilakukan akan terfokus pada performa kedudukan 


\section{ISSN: $X \times 32$

panel surya dalam pengontrolan penangkapan cahaya matahari datang hingga terbenam agar mencapai kondisi yang diinginkan saat pengontrolan sistem terhadap panel surya. Hasil eksprimen ini selanjutnya didokumentasikan untuk melakukan analisa sehingga dapat memahami cara kerja dari panel surya. Dari hasil analisa tersebut nantinya akan mendapatkan kesimpulan proses yang terjadi pada penangkapan cahaya matahari dalam mengunakan panel surya berbasis Arduino

\section{Metode Perancangan Sistem}

\section{Blok Diagram Global}

Blok diagram global yang digunakan dalam perancangan penelitian ini adalah sebagai berikut:

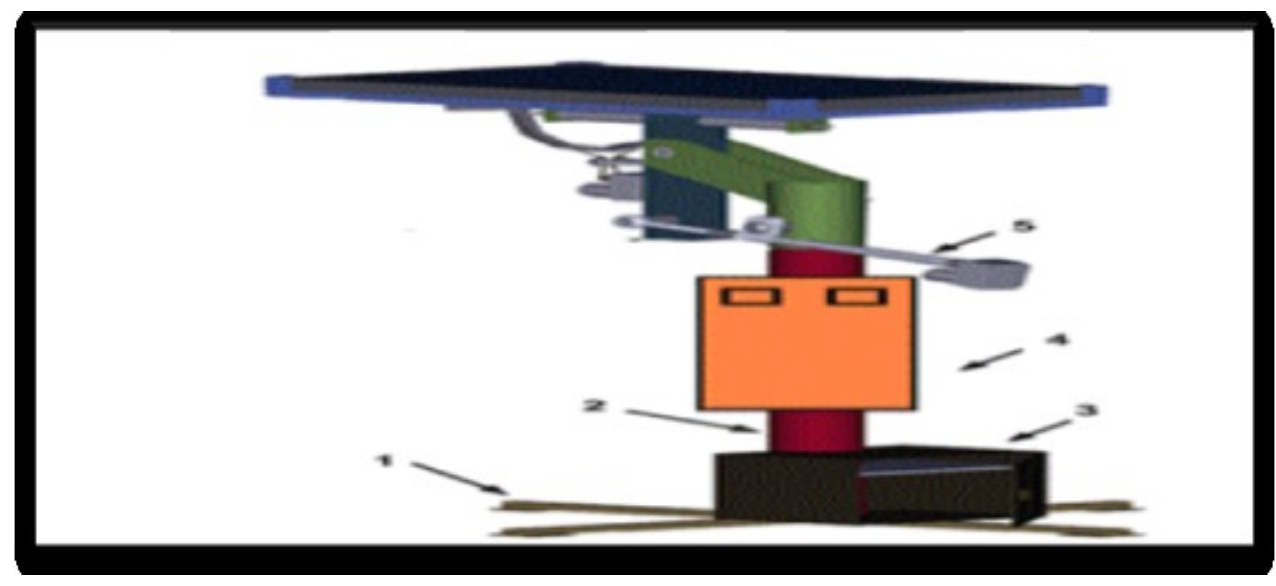

Gambar 3.1 Blok Diagram Global

Keterangan gambar :

1. Kaki

2. Tiang utama

3. Aki

4. Mikrokontroler arduino, RTC, Driver motor,kontroler dan baterai

5. Motor penggerak

6. Panel Surya

Pada gambar 3.1 blok diagram global diatas, dapat dijelaskan bahwa secara keseluruhan alat pengujian yang dilakukan terhadap gabungan seluruh rangkaian elektronik, motor dan rangka alat serta alat pendukung lainnya dapat bekerja menggerakkan dan mengikuti posisi dimana matahari berada, kemudian arduino yang dihidupkan akan bekerja mencari sumber cahaya matahari dan kabel panel surya dihubungkan pada baterai sebagai tempat penyimpanan energi yang dihasilkan oleh panel surya. 


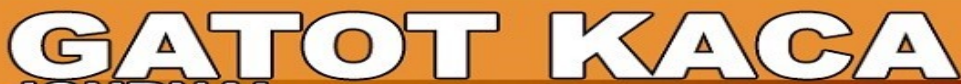 JOURNAL}

\section{Blok Diagram Rangkaian ALat}

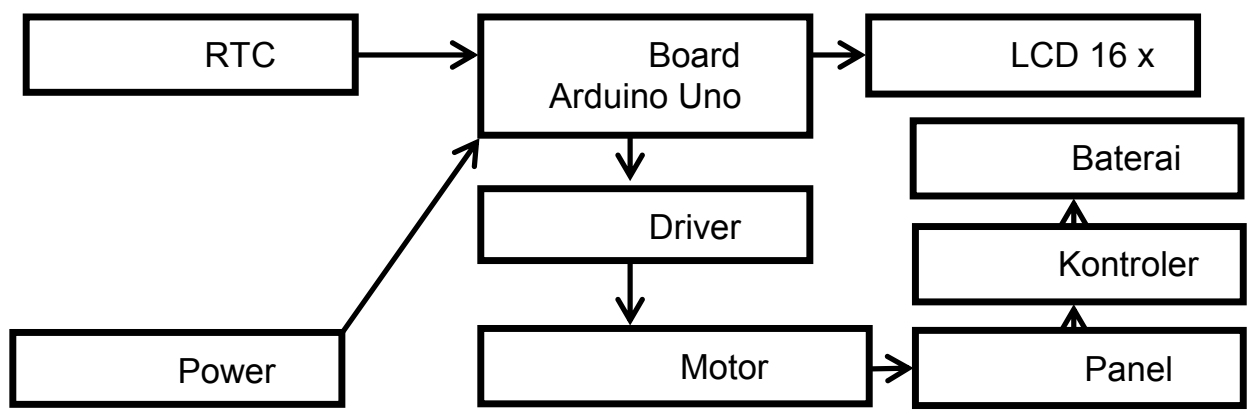

Keterangan gambar :

1. RTC adalah Real Time Clock yang berfungsi menyimpan waktu secara realtime, yaitu tanggal, bulan, hari, tahun, jam, menit, dan detik.

2. Board arduino untuk mengolah rangkaian alat

3. Lcd untuk menampilkan hasil data

4. Driver motor digunakan untuk menggerakkan motor penggerak

5. Panel Surya adalah objek penelitian yang akan diukur arus dan teganganya dalam uji coba alat

6. Kontroler adalah bagian dari alat yang mengolah arus dan tegangan dari panel surya

7. Baterai penyimpan sumber arus yang akan digunakan untuk menghidupkan berbagai peralatan elektronik.

\section{Desain Rangkaian}

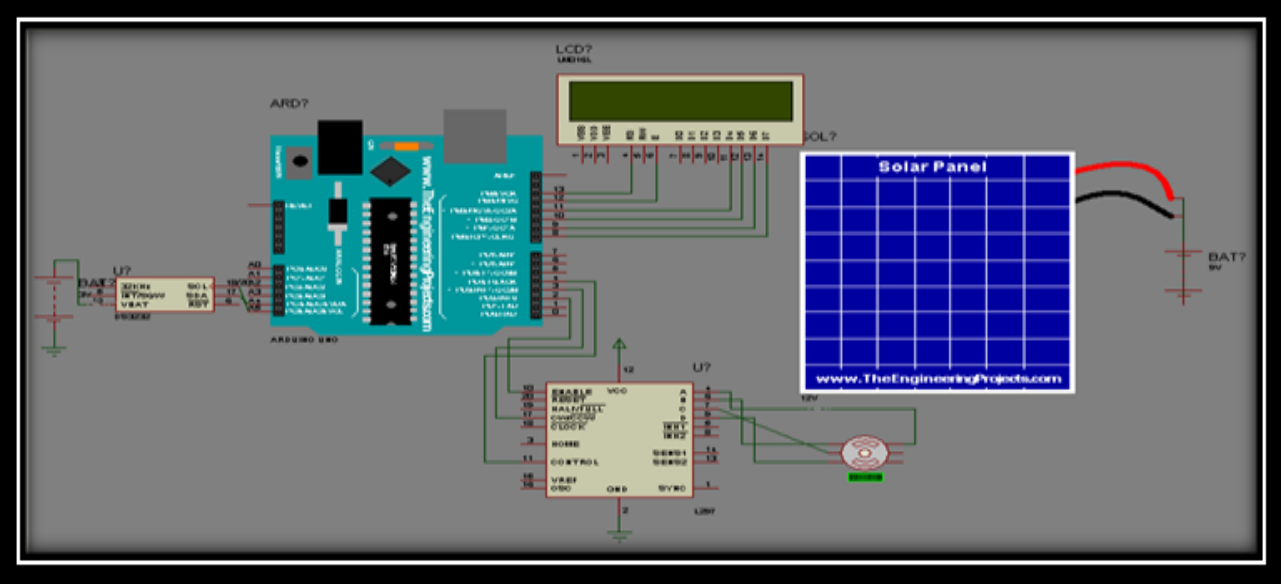

Gambar 3.3 Desain Rangkaian

Keterangan :

Salah satu hal penting yang perlu diperhatikan adalah untuk mencocokkan kapasitas panel surya dengan Amp-Jam baterai, sehingga baterai dengan kapasitas 72Ah harus 
dihubungkan panel surya tidak lebih dari 6 amp. Gambar rangkaian diatas mengilustrasikan untuk kapasitas 72Ah.

\section{Prinsip Kerja Sistem}

Prinsip kerja alat ini adalah ketika alat dihidupkan maka arduino akan membaca data dari RTC berupa waktu, kemudian akan menggerakkan motor penggerak sehingga panel surya bergerak setiap 10 menit sekali. Sudut gerak dari panel surya yaitu tegak lurus dengan arah matahari mulai dari pukul 08.00 sampai pukul 15.00 .

\section{Rencana Kerja Sistem}

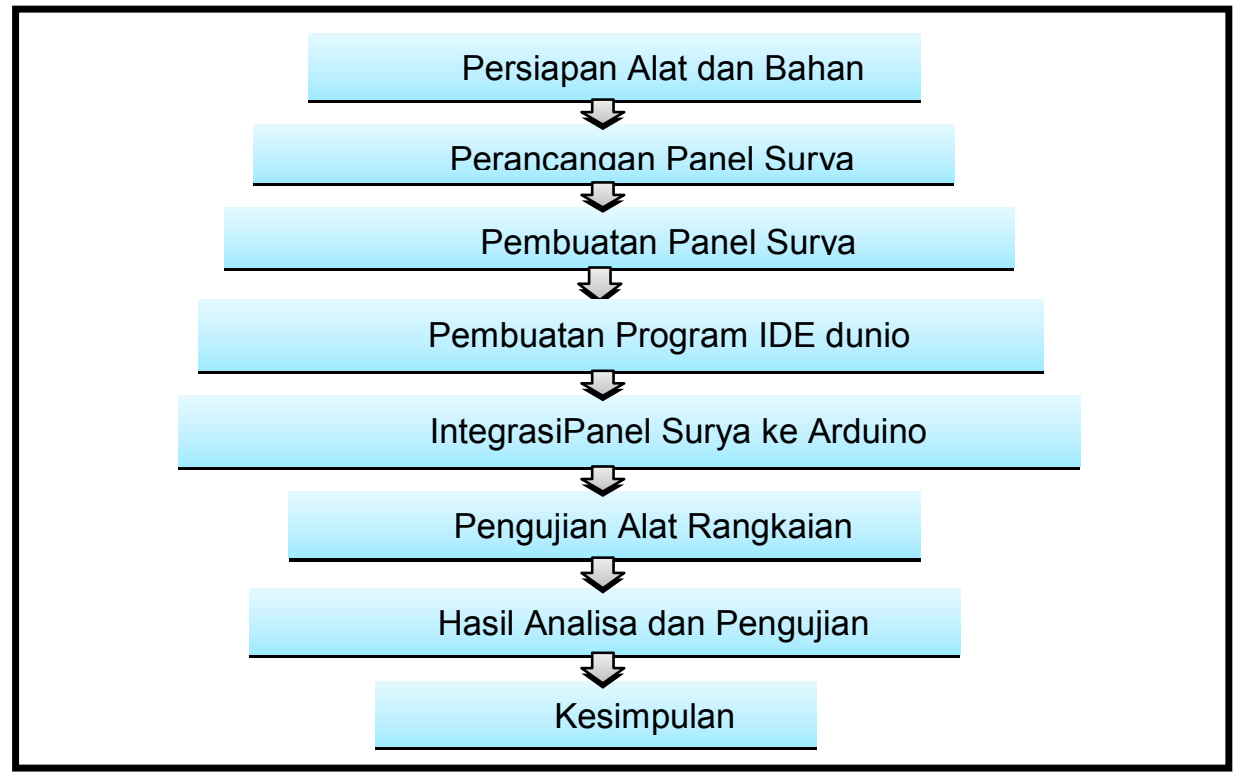

Gambar 3.4 Rencana Kerja

\section{E. Rancangan Pengujian}

Pengujian ini dilakukan dengan metode blackbox, yaitusebuah metode yang digunakan untuk menemukan kesalahan dan mendemonstrasikan fungsi rangkaian alat saat dioperasikan, apakah input diterima dengan benar dan output yang dihasilkan telah sesuai dengan yang diharapkan, sehingga dapat membuktikan kebenarannya. : 


\section{CATOT WAGA

\begin{tabular}{|c|c|c|c|c|c|c|c}
\hline \multicolumn{3}{|c|}{ Panel Surya Bergerak } & \multicolumn{5}{c}{ Panel Surya Tetap } \\
\hline NO & Waktu & Arus & Tegangan & NO & Waktu & Arus & Tegan \\
\hline 1 & 08.00 & & & 1 & 08.00 & & \\
\hline 2 & 11.00 & & & 2 & 11.00 & & \\
\hline 3 & 12.00 & & & 3 & 12.00 & & \\
\hline 4 & 15.00 & & & 4 & 15.00 & & \\
\hline
\end{tabular}

\section{Pembahasan}

\section{HASILDAN PEMBAHASAN}

Hasil analisa sistem gerak panel suryaberbasis Arduino Uno, pada Panel Surya ini menggunakan Arduino Uno sebagai sistem gerak untuk mengikuti arah matahari, RTC digunakan sebagai penerimaan perintah yang dikirim melalui panel surya agar dapa membaca kisaran sudut, stepper difungsikan sebagai penggerak panel surya yang dikendalikan menggunakan Arduino Uno menggunakan aplikasi.

Dalam penelitian ini penulis mendapatkan hasil sebagai berikut :

\section{Pengujian Rangka Panel Surya}

Dalam pembuatan sistem gerak panel surya yang dikendalikan menggunakan Arduino Uno dapat dilihat pada gambar berikut :

1. Tampak Depan

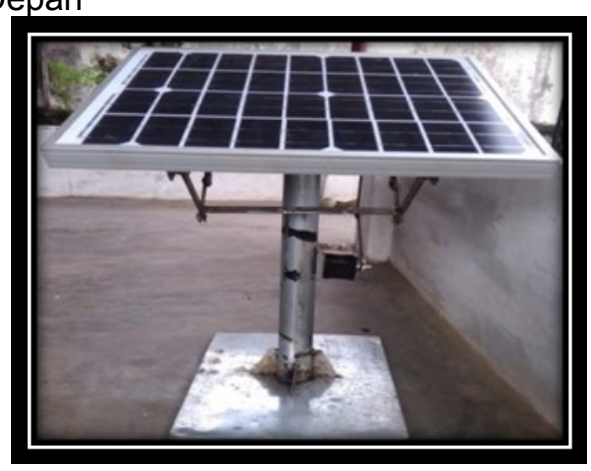

Gambar 4.1 Tampak Depan Panel

2. Tampak Atas 


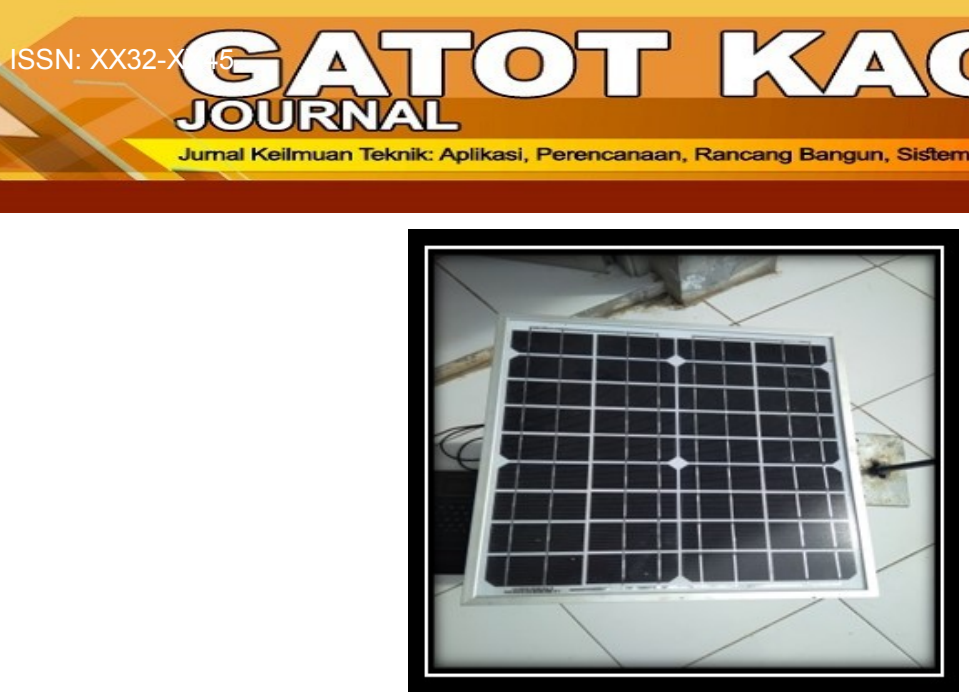

Gambar 4.2 Tampak Atas Panel

3. Tampak Samping

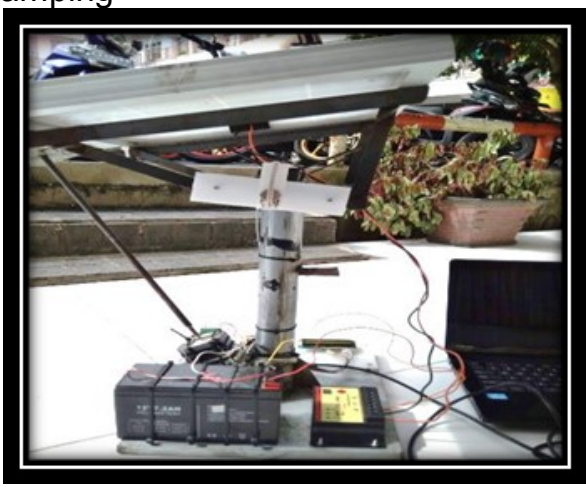

Gambar 4.3Tampak Samping Panel

\section{Pengujian Listing Program}

Hasil yang akan di peroleh dalam menggunakan aplikasi Arduino IDE ini berupa listing program sehingga kita akan mengetahui kode program yang akan dikirim dan diterima olehseluruh rangkaian dalam pengendalian panel surya yang akan di upload kedalam mikrokontroller Arduino Uno dengan menggunakan sebuah PC dan bahasa pemogramansketch. Kode program ini dapat diketahui ketika menghidupkan rangkaian pada panel surya dan terhubung pada bateray yang akan menggerakan aktuator, program ini dapat dilihat pada gambar 4.4 dan untuk lebih jelasnya lagi bisa dilihat pada lampiran. 


\section{E/A}

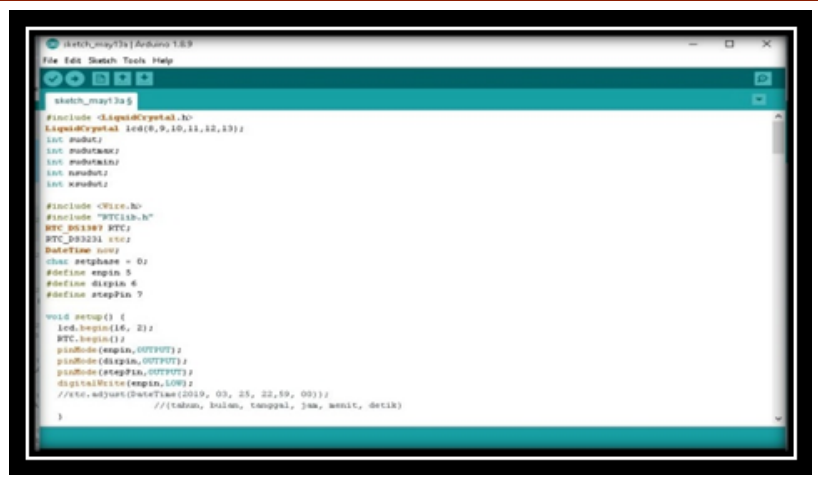

Gambar 4.4 Listing Program Sketch

\section{Pengujian Gerak Panel Surya}

Dalam pengujian ini penulis melakukan pengujian secara keseluruhan pada rangkaian Panel Surya. Dan akan mendapat hasil sebagai berikut :

1. Pergerakan Panel Surya ke Arah Timur

2. Pergerakan Panel Surya Tegak Lurus Terhadap Matahari

3. Pergerakan Panel Surya ke Arah Barat

Saat terhubungnya rangkaian panel surya pada baterai $12 \mathrm{v}$ secara otomatis panel bergerak berdasarkan sudut dan waktu yang telah ditentukan pada listing program sketch yang mana panel bergerak mengikuti arah datang cahaya matahari.

\section{Persiapan Alat dan Bahan}

Alat dan bahan dalam melakukan penelitian dan analisa untuk panel surya berbasis Arduino Uno ini memerlukan pemilihan komponen yang tepat karena sangat mempengaruhi sistem kerja pada alat.

Adapun komponen yang diperlukan untuk pembuatan alatadalah sebagai berikut :

1. Panel Surya(fotovoltaik), merupakan suatu integrasi dari rangkaian sel surya yang disusun untuk mendapatkan besaran arus dan tegangan tertentu.

2. Sensor adalah suatu peralatan yang berfungsi untuk mendeteksi gejala-gejala atau sinyal-sinyal yang berasal dari perubahan suatu energi, sensor yang digunakan dalam penelitian ini adalah sensor RTC.

3. RTC adalah jam elektronik berupa chip yang dapat menghitung waktu (mulai detik hingga tahun) dengan akurat dan menjaga/menyimpan data waktu tersebut secara real time. Arduino Uno adalah papan sirkuit berbasis mikrokontroler. IC (integrated circuit) ini memiliki 4 input/output, Lcd adalah sebuah peralatan eletronik yang berfungsi untuk menampilkan output pada layar. Maka secara efisien kita dapat melihat hasil pada layar $L C D$.

4. Driver Motor adalah komponen yang berfungsi untuk mengkomunikasikan antarakontroler dengan aktuator serta memperkuat sinyal keluaran dari kontroler sehingga dapat dibaca oleh aktuator.

5. Stepper Aktuator adalah suatu peralatan yang terdiri dari perangkat elektronik dan mekanik yang terletak pada tiang penyanggah, yang berfungsi untuk menggerakkan dan mengarahkan agar didapatkan posisi yang mengarah tepat kesatelit yang dikehendaki, namun pada penelitian ini Actuator berfungsi sebagai penggerak panel surya pada saat mencari posisi cahaya atau panas matahari. 
6. BateraiAki adalah media penyimpan muatan listrik. Secara garis besar aki dibedakan berdasarkan aplikasi dan kontruksi.

Dengan demikian aki ini bisa menyuplai arus listrik yang besar pada saat awal untuk menghidupkan mesin. Aki deep cycle biasanya digunakan untuk sistem fotovoltaik (solar cell) dan back up power, dimana aki mampu mengalami discharge hingga muatan listriknya tinggal sedikit.

7. Multitester untuk mengukur arus dan tegangan pada panel surya.

8. obeng, serta perlengkapan yang dibutuhkan.

\section{Perancangan Panel Surya}

Dalam pembuatan suatu alat agar mendapatkan kegunaan yang tepat dan bisa dapat melayani kebutuhan beban dengan baik maka harus melewati suatu perencanaan atau perancangan. Maka alat tersebut harus memiliki bagian - bagian atau blok rangkaian yang saling terhubung atau terkait antara blok rangkaian yang satu dengan blok rangkaian yang lain seperti pada diagram blok.

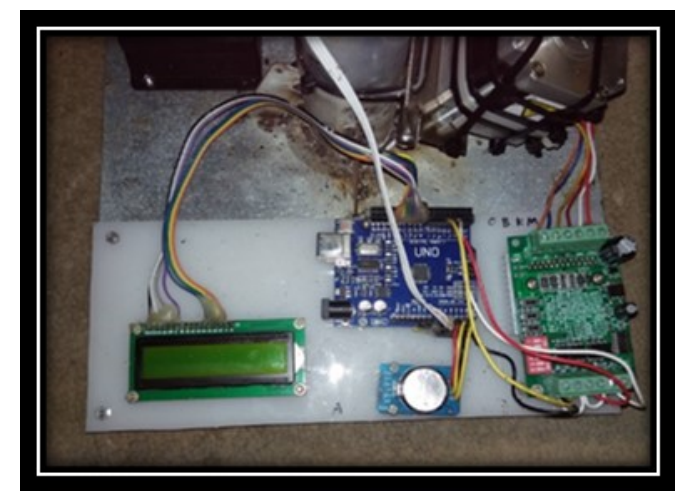

Gambar 4.5 Tampilan Rangkaian Panel Surya

\section{Pembuatan Panel Surya}

Dalam pembuatankerangka panel surya agar dapat mencapai kedudukan yang diinginkan, yaitu permukaan panel surya harus tegak lurus terhadap cahaya matahari, maka kerangka memiliki 2 sisi yang dapat bergerak bebas pada putaran $180^{\circ}$.

Adapun langkah pembuatan pada Panel Surya ini sebagai berikut:

a. Langkah pertama dalam pembuatan, yaitu dengan mengelas bagian-bagian dari tiang penyangga untuk panel surya. Terlihat pada gambar berikut: 


\section{G/ATOT RAGA

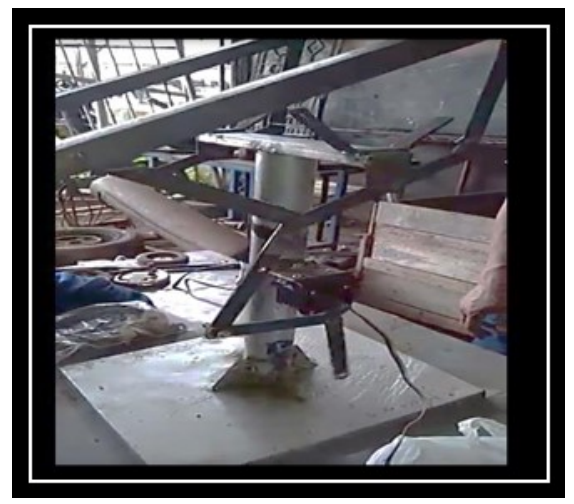

Gambar 4.6 Tiang Penyangga Panel Surya

b. Langkah kedua perakitan komponen-komponen pelengkap terhadap panel surya. Terlihat pada gambar berikut:

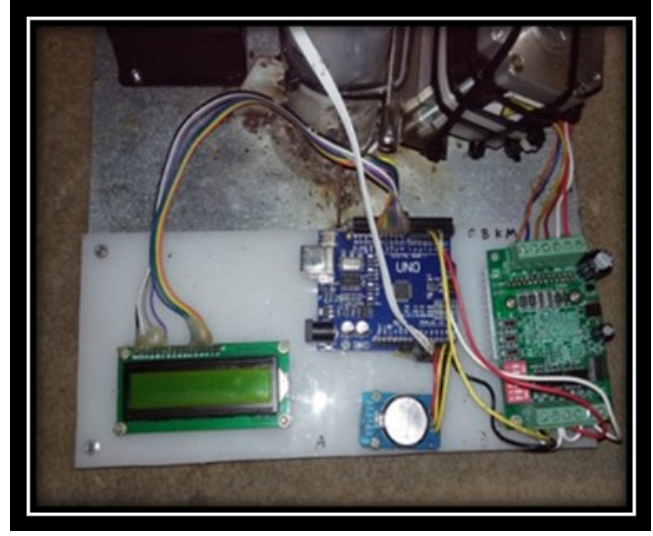

Gambar 4.7 Rangkaian Komponen Panel Surya

c. Langkah terakhir dapat terlihat pada gambar ilustrusi berikut:

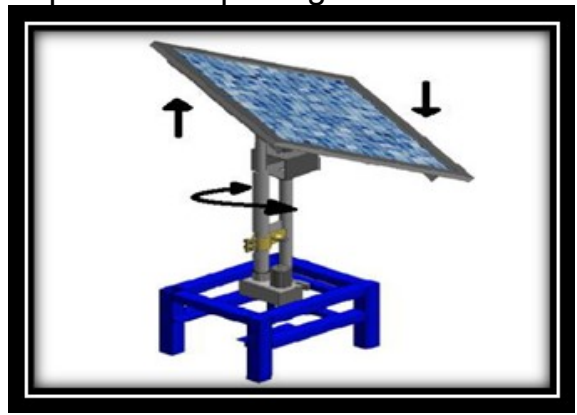

Gambar 4.8 Kerangka Panel Surya

Pembuatan Program Aplikasi Arduino IDE

Arduino IDE adalah software yang sangat canggih ditulis dengan menggunakan Java. IDE Arduino terdiri dari: 
ISSN: $X \times 32$

1.Editor program, adalah windows yang memungkinkan pengguna untuk menulis dan mengeditprogram dalam bahasa Processing.

2. Compiler, adalah modul yang mengubah kode program (bahasa Processing) menjadikode biner. Karena microcontroller tidak akan bisa memahami bahasaProcessing. Yang bisa dipahami oleh microcontroller adalah kode biner. Itulah sebabnyacompilersangat diperlukan dalam hal ini.

3. Uploader, adalah modul yangmemuat kode biner dari komputer ke dalam memori didalam papan Arduino.

Kode program Arduino umumnya disebut dengan istilah sketch. Kata "sketch" digunakan secara bergantian dengan "kode program" dimana keduanyamemiliki arti yang sama.

\section{Integrasi Panel Surya ke Arduino}

a. Buka aplikasi IDE duino pada desktop maka akan tampil gambar berikut:

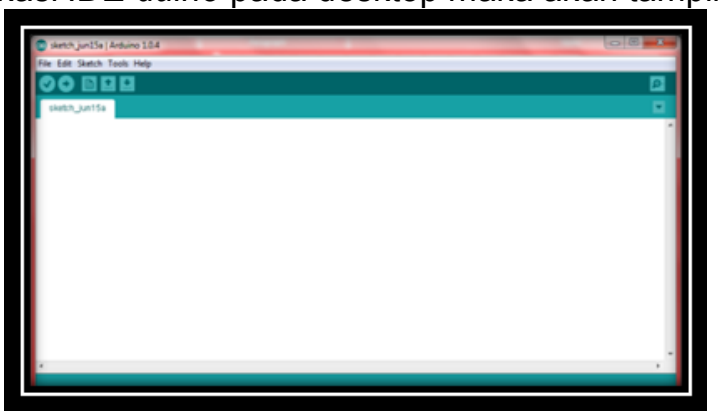

Gambar 4.9 Tampilan Awal Pada Aplikasi IDE Duino

b. Mengetik program dengan mengunakan bahasa pemograman sketchIDE duino.

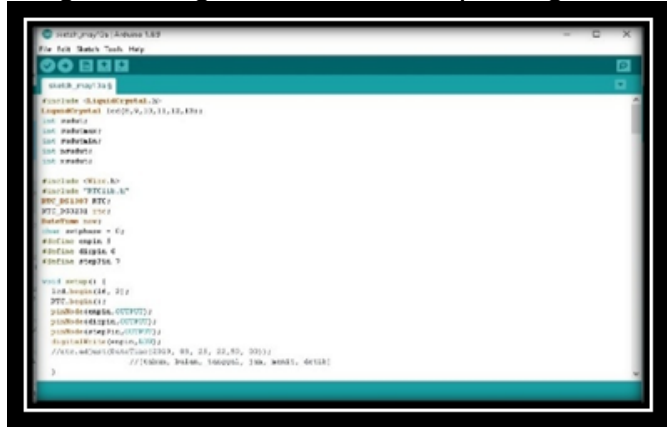

Gambar 4.10 Lembar Proses Pengeditan Program

c. Proses verifyte, untuk memeriksa apa ada kesalahan dalam penulisan program. 


\section{CAAOT RAGA

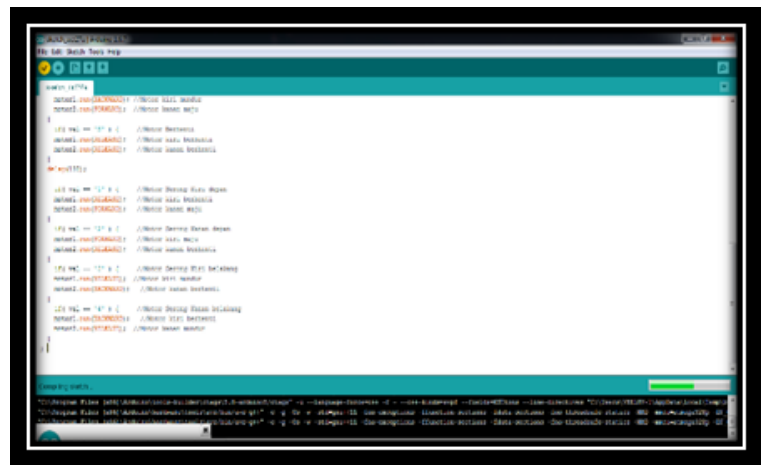

Gambar 4.11 Tampilan Proses Verifyte

d. Kemudian apabila tidak terdapat kesalahan, maka program telah siap untuk diupload pada board arduino.

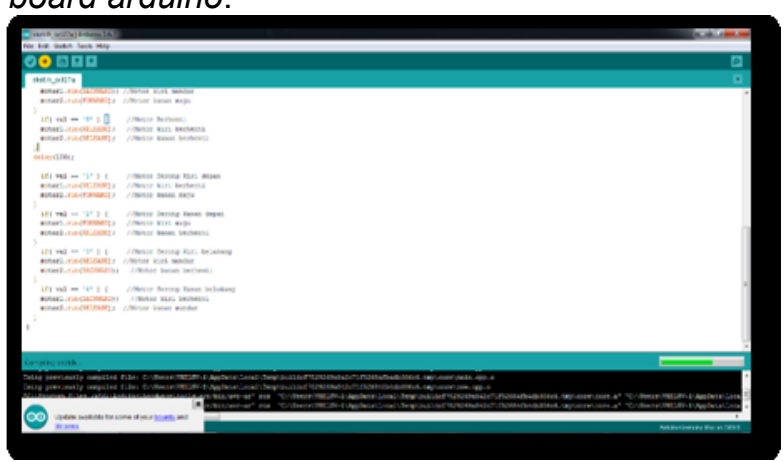

Gambar 4.12 Proses Upload pada Board Arduino

\section{Pengujian Alat Rangkaian}

Pengujian dilakukan pada perangkat keras dan keseluruhan system yang terdapat dal am peralatan ini.Pengujian ini dilakukan dengan cara melakukan pengukuran pada aru $s$ dan tegangan terhadap masing masing panel,sehingga didapat perbandingan antara hasil pengujian yang didapat dengan perancangan sistem. Dan juga dapat dianalisa apa kah system pada panel surya ini berfungsi dengan baik dan stabil.Tujuan dari pengukur an system ini adalah mengetahui apakah perangkat keras yang telah dibuat dapat beke rja dengan baik.Dan dapat kita lihat pada gambar berikut:

a. Pengujianlangsungpada panel suryadibawahterikmatahari

b. 


\section{ISSN: XX32-

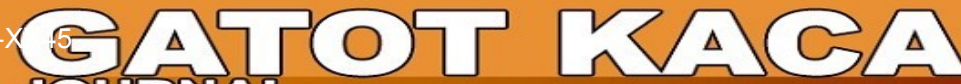

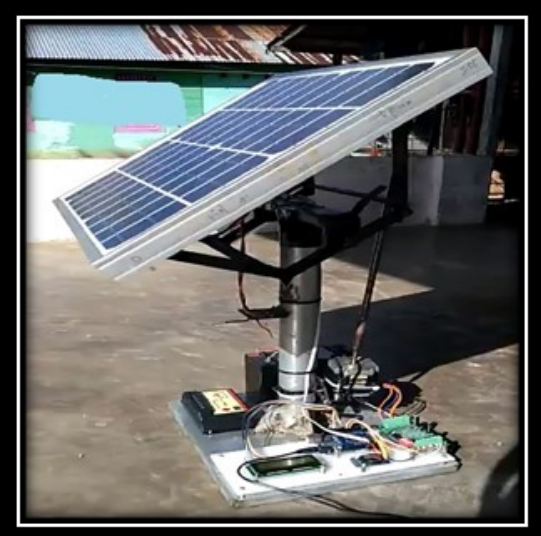

Gambar 4.13 UjiCoba Panel DibawahTerikMatahari

c. Pengukuranaruspada panel suryaterhadapmataharilangsung

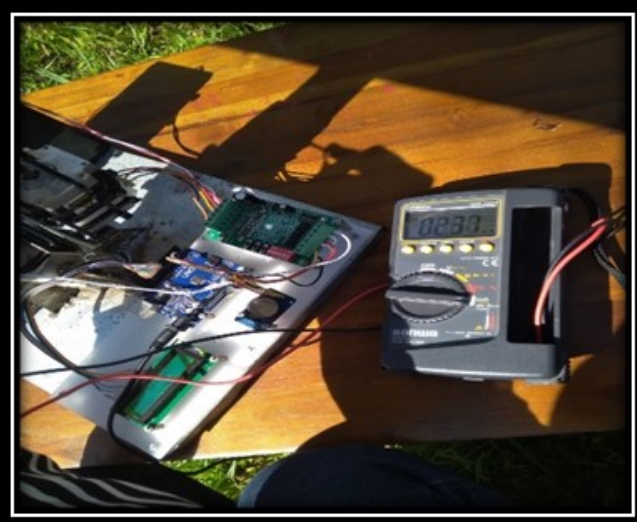

Gambar 4.14 PengukuranArus Panel Surya

d. Pengukuranteganganpada panel suryaterhadapmataharilangsung. 


\section{EAtAOT RACA}

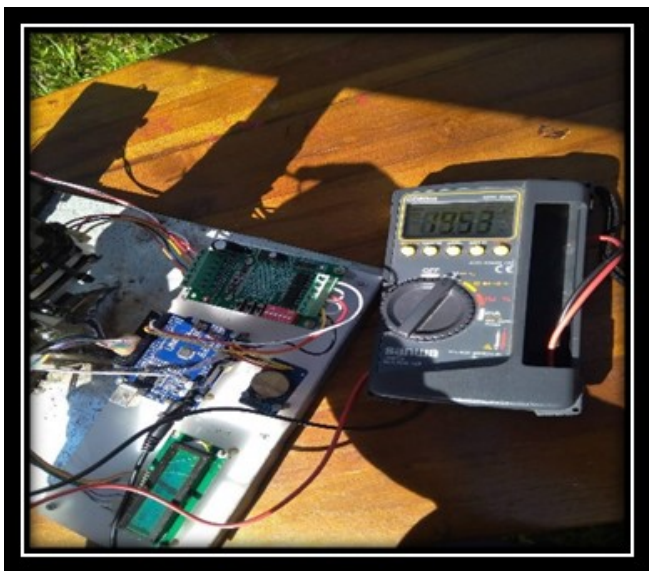

Gambar 4.15 PengukuranTegangan Panel Surya

Setelah melakukan Pengujian, maka pengamatan atau analisa dilakukan untuk mengetahui keseluruhan hasil kerja pada sistem panel surya. Dan hasil dari pengujian dan pengamatan ini akan dimasukkan pada tabel pengujian alat.

\section{KESIMPULAN DAN SARAN}

\section{Kesimpulan}

Setelah perancangan, perencanaan sistem dan pengujian serta analisanya, maka dapat diambil beberapa kesimpulan tentang sistem gerak panel surya berbasis Arduino Uno yang dibuat oleh penulis :

1. Perancangan panel surya meliputi perancangan desain penyanggah panel, perancangan konfigurasi kabel antara Arduino Uno, motor penggerak, sehingga panel surya dapat dikendalikan user melalui baterai.

2. Berdasarkan pengujian menggunakan panel surya bergerak, total jumlah energi yang dihasilkan lebih besar dibandingkan dengan panel surya diam.

3. Dari hasil pengujian didapatkan bahwa tingkat jumlah tegangan tertinggi berada pada jam 11.00 sampai 12.00. hal ini disebabkan karena matahari tepat berada di atas lintas edar matahari harian.

4. Pengukuran arus dan tegangan pada panel surya pukul 11.00 wib berada pada titik sudut $108^{\circ}$ dengan arus $02.45 \mathrm{~mA}$ dan tegangan $20.52 \mathrm{v}$ sedangkan pukul $12.00 \mathrm{wib}$ berada pada titik sudut $144^{\circ}$ dengan arus $02.49 \mathrm{~mA}$ dan tegangan 20.62v. Jadi hasil yang maksimum berada pada pukul 12.0 wib.

5. Sistem gerak panel surya berbasis Arduino Uno dapat menggerakkan panel surya mengikuti pergerakkan matahari berdasarkan waktu dengan besar sudut yang telah ditentukan.

6. Berdasarkan pengujian panel surya berbasis Arduino Uno dapat menghasilkan tegangan optimal dengan posisi panel surya berada tegak lurus terhadap matahari. Panel surya digerakkan oleh aktuator ke sudut yang telah ditentukan dengan settingan waktu per menit sehingga panel surya dapat berada tegak lurus terhadap sinar datang dari cahaya matahari. 


\section{ISSN: $X \times 32$

\section{Saran}

Berdasarkan hasil pengujian dan hasil analisa yang telah penulis lakukan maka penulis memiliki saran agar alat ini dapat dikembangkan lagi yang memiliki teknologi yang lebih canggih untuk kedepannya tetap menggunakan Arduino Uno dengan menambahkan intensitas cahaya saat terjadinya hujan.

\section{DAFTAR PUSTAKA}

Putra, P.Y.A2007, Perancangan Dan Pembuatan Simulasi Pembangkit Listrik Tenaga Surya (PLTS). UNDIKSHA.

Naibaho,1994 Teknik Tenaga Listrik Tenaga Surya, Malang, PPPGT VEGT.

Najmurrokhman, dkk,2010, 25 mei. "Prototipe Pembangkit Listrik Tenaga Matahari", Prosiding Seminar Nasional "Sains dan Teknologi dalam Penanganan Energi" , Cimahi, ISBN 978-979-98582-2-, pp.32 - 41.

Suryana, D. Widyariset. 2016, Otomatisasi Pada Panel Surya Menggunakan Panel Surya Tracking Aktif Tipe Singgle Axis.Balai Riset Industri Surabaya Vol.2 No.1

Firmansyah, RancangBangunSistemKontrolPenggerak Panel Sel Surya Berbasis Program Mabble Logic Controller , JurnalSwateknologiVol 2, No 2. PoliteknikSwadharma.

Zuhal.1988. DasarTeknikTenagaListrikdanElektronikaDaya. Jakarta: PT Gramedia http://fredikurniawan.com/pengertian-sistem-secara-umum-dan-menurut-para-ahli/

Anonymous. 2014 “unjuk kerja PLTS 1920 Watt Di Fakultas Teknik Elektro Universitas Udayana Bukit Jimbaran.

Banzi, Massimo. “Gretting Started with Arduino”.O’Reilly.2008 (diakses 10 januari 2017 http://www.arduino.cc

Ismail Y.2012."Optimasi Penyerapan Sinar Matahari Menggunakan Sistem Tracking Pada Modul Sel Surya" Jurnal Elekro ELTEK, Vol 1 No: 1,2010.

Prabawa, Benny 2015 "Rancang bangun Sistem Panel Surya Berbasis Mikrokontroler Arduino" Journal SPEKTRUM Vol 2, No. 2 Juni 2015

Rhazio 2007, "Pembangkit Listrik Tenaga Surya" Institut Sains \& Teknologi Al-KamalJakarta 